\title{
Elevated serum bromide concentrations following repeated halothane anaesthesia in a child
}

\begin{abstract}
A 20-month-old child received 25 brief halothane general anaesthetics over a five-week period to allow cranial irradiation treatments for a posterior fossa ependymoma. Personality change during the last week of the treatment protocol raised the question of possible bromide intoxication. Serum bromide concentrations, using a gold chloride assay technique, were monitored at that time, and at four-and six-week intervals thereafter. Serum bromide concentrations demonstrated a four-fold change during this period ranging from peak levels of $2.2 \mathrm{mEq} \cdot \mathrm{L}^{-1}\left(176 \mu \mathrm{g} \cdot \mathrm{kg}^{-1}\right)$ during the fifth week of treatment decreasing to $<0.5 \mathrm{mEq} \cdot \mathrm{L}^{-1}\left(<40 \mu \mathrm{g} \cdot \mathrm{ml}^{-1}\right)$ six weeks following the end of trearments. This demonstrates the possibility for repetitive, short halothane exposures 10 result in elevations of serum bromide and the potential of bromide intoxication in paediatric neuro-oncology patients.
\end{abstract}

Un enfant âgé de 20 mois a reçu 25 anesthésies générales de courte durée avec l'halothane pour une période de cinq semaines lors d'une thérapie de radiation crânienne pour un épendymome de la fosse postérieure. Des changements de la personnalité durant la dernière semaine du traitement ont amené à soulever la question d'une possibilité d'intoxication au bromure. Des concentrations de bromure sérique ont été surveillées à ce moment-là et à des intervalles de quatre et six semaines plus tard. Des concentrations de bromure sérique ont démontré une augmentation au quadruple pendant cette période s'étendant d' un peak de 2,2 $\mathrm{mEq} \cdot \mathrm{L}^{-1}\left(176 \mu \mathrm{g} \cdot \mathrm{ml} \mathrm{l}^{-1}\right)$

\section{Key words}

ANAESTHESIA: paediatric;

ANAESTHETICS, VOLATILE: halothane;

BIOTRANSFORMATION (DRUG): bromide; IONS: bromide.

From the Department of Anesthesiology, The Children's Hospital, 1056 East 19th Avenue, Denver, Colorado, 80218, USA.

Address correspondence to: Dr. J. E. Morrison. durant la cinquième semaine du traitement pour diminuer à $<0,05 \mathrm{mEq} \cdot \mathrm{L}^{-1}\left(<40 \mu \mathrm{g} \cdot \mathrm{ml}^{-1}\right)$ six semaines après le début des traitements. Ceci démontre la possibilité que des expositions répétitives de courte durée à l'halothane peuvent amener une élévation du bromure sérique qui peut être potentiellement toxique pour les patients pédiatriques admis en neuro-oncologie.

Halothane is commonly used in paediatric anaesthesia. While prolonged exposure to high doses of this anaesthetic is known to result in elevated bromide concentrations, ${ }^{1.2}$ and symptoms of bromide toxicity can occur, the effect of frequent, but short exposures to halothane has not been reported previously. The following is a case report of a 20 -month-old child requiring 25 irradiation treatments to the posterior fossa over a five-week period, performed under halothane general anaesthesia, who demonstrated a four-fold elevation of her serum bromide concentration.

\section{Case report}

The patient was originally diagnosed at age $8 \frac{1}{2}$ mo with malignant ependymoma of the fourth ventricle. Because of her young age, radiation therapy was deferred at that time, and she was treated with chemotherapy (including cis-platinum). Recurrent disease was found at the end of that therapy, and radiation was begun. The treatment protocol required the child to receive 4500 centiGray to the posterior fossa in 180 centiGray daily doses. To accomplish this the child would be required to lie quietly alone in the linear accelerator room for approximately ten minutes, in the prone position. Because of her temperament and young age, the child was incapable of such compliance, and a paediatric anaesthesia consultation was requested.

It was decided that general anaesthesia with halothane/ $\mathrm{N}_{2} \mathrm{O} / \mathrm{O}_{2}$ would offer an acceptable approach in these unique circumstances. Remote monitoring could be achieved via microphone and videocamera. The child was fasted for six hours prior to the anaesthetic (i.e., break- 
fast, then fasted pending induction of anaesthesia at 1300 $\mathrm{hr}$ from Monday to Friday), and had no premedication. An indwelling intravenous line (Broviac ${ }^{\otimes}$ catheter) was in place should that be required for emergency access, but routine use of that line was minimized by the anaesthesia team to avoid potential sepsis. Following placement of ECG, precordial stethoscope, blood pressure cuff, and pulse oximeter, mask induction of anaesthesia was followed by tracheal intubation ( $3.5 \mathrm{~mm}$ tube). A small tube was specifically chosen, with a leak at $6-12 \mathrm{~cm} \mathrm{H}_{2} \mathrm{O}$, in view of the numerous intubations that she would receive. She was then turned into the prone position and secured in a foam-padded headrest. Videocamera monitoring was focused on the ECG/oximeter monitors while the child was anesthetized. Anaesthesia was maintained, breathing spontaneously on 0.5 per cent halothane with $1.5 \mathrm{~L} \cdot \mathrm{min}^{-1} \mathrm{~N}_{2} \mathrm{O}$ and $\mathrm{O}_{2}$ using a semi-closed circle system with $\mathrm{CO}^{2}$ absorber. At the halfway point during the radiation, or if repositioning of the linear accelerator was necessary, the anaesthesia team re-entered the room to assess the child, monitor blood pressure, and recheck the anaesthesia circuit. No problems in this regard were encountered during the 25 treatments.

After the first week of radiation treatments the child became ataxic and was given oral steroids which resulted in resolution of her gait abnormality. This initial change was thought to be due to the effects of local irradiation (i.e., oedema) in the posterior fossa. During the fourth week of treatment she was noted to be feisty during the Monday session, but became increasingly passive as the week progressed. At this time the possibility of bromide intoxication was raised and it was decided to monitor her serum bromide concentrations. Six millilitre blood samples were obtained via the Broviac ${ }^{\circledR}$ catheter and serum was forwarded for assay (Roche Biomedical Laboratories, Sacramento, CA) which was performed using a gold-chloride technique. Three specimens were obtained during the last week (i.e, Monday, Wednesday, and Friday) of her treatment, one the following Monday, and in lieu of a prior control sample, specimens were obtained four and six weeks later to reflect her baseline bromide level. She was receiving no bromide-containing medications, did not receive pancuronium bromide during her anaesthetics, and the water in her neighbourhood had maximum bromide concentrations less that $0.1 \mathrm{mg} \cdot \mathrm{ml}^{-1}$.

The assay data are listed in the Table. Peak bromide concentrations were $2.2 \mathrm{mEq} \cdot \mathrm{L}^{-1}\left(176 \mu \mathrm{g} \cdot \mathrm{ml}^{-1}\right)$ during the fifth week of halothane exposure, decreasing to $<0.5$ $\mathrm{mEq} \cdot \mathrm{L}^{-1}\left(<40 \mu \mathrm{g} \cdot \mathrm{ml}^{-1}\right)$ six weeks after completion of therapy and cessation of halothane exposures.

\section{Discussion}

This case report demonstrated a four-fold increase in the serum bromide concentration of a young child receiving serial brief halothane anaesthetics. Previous reports of bromide elevations concerned adult patients after single halothane exposures. ${ }^{1,2}$ The data we report occurred in a paediatric patient who demonstrated some clinical changes (e.g., ataxia, subtle personality alterations) which could be attributable to (1) her underlying tumour, (2) side-effects of the cranial irradiation treatment, or (3) as a result of bromide intoxication. ${ }^{3.4}$

General anaesthesia with halothane was selected for several reasons. It was not thought that sedation alone (e.g., chloral hydrate, barbiturates) would be reliable or safe - given the physical circumstances in the radiation therapy department. Ketamine was not considered in view of the possibility of psychological sequelae following daily administration to a patient with brain tumour ${ }^{5}$ and potential for increased intracranial pressure and seizures. ${ }^{6}$ The requirement for prone positioning made us hesitant to maintain the airway without intubation in view of data citing loss of airway control as a major factor in paediatric anaesthetic-related cardiac arrests, although the use of such technique has been reported for radiation therapy. ${ }^{8.9}$ Our patient did not develop hoarseness, stridor or other signs of airway oedema throughout her treatment, and had rapid emergence, within minutes, each day.

Halothane is considered to be the agent of choice for short therapeutic procedures in children with malignancies $^{10}$ and has been previously reported ${ }^{11}$ to be safe for repeated administrations over a six-week period, while the usc of isoflurane for mask inductions has been associated with an unacceptably high incidence of laryngospasm in children. ${ }^{12}$

Bromide intoxication, as described by Johnstone et al. ${ }^{1}$ is characterized by lethargy, dizziness, ataxia, mental confusion, hallucinations, and other central nervous system symptoms. They reported serum bromide elevations of $2.5 \pm 0.1 \mathrm{mEq} \cdot \mathrm{L}^{-1}$ following halothane exposure (without surgery) which they stated might account for prolonged changes in mood and intellectual function. Tinker $e t a l^{2}$ also reported 25 adult patients receiving halothane with subsequent bromide concentrations (up to

TABLE Serum bromide concentrations

\begin{tabular}{|c|c|c|c|}
\hline \multirow[b]{2}{*}{ Day of week } & \multirow{2}{*}{$\begin{array}{l}\text { Anaesthetic } \\
\text { number }\end{array}$} & \multicolumn{2}{|c|}{ Bromide levels } \\
\hline & & $\left(m E q \cdot L^{-1}\right)$ & $\left(\mu g \cdot m l^{-1}\right)$ \\
\hline Monday & 20 & 1.4 & 111.9 \\
\hline Wednesday & 22 & 1.5 & 119.8 \\
\hline Friday & 24 & 2.2 & 175.8 \\
\hline Monday & 25 & 2.2 & 175.8 \\
\hline 4 weeks later & & 1.4 & 111.9 \\
\hline 6 weeks later & & $<0.5$ & $<40.0$ \\
\hline
\end{tabular}


$2.25 \mathrm{mEq} \cdot \mathrm{L}^{-1}$ ) peaking at $48-72 \mathrm{hr}$ after anaesthesia but persisting for as long as 22 days, and being in the sedative and possibly the toxic range. While they note that the CNS toxic range is normally considered to be $6 \mathrm{mEq} \cdot \mathrm{L}^{-1}$ or higher in patients partially tolerant to bromide, Greene, in an accompanying editorial, ${ }^{13}$ commented that most surgical patients today are not routinely on chronic bromide therapy and that these ranges of serum bromide concentrations could be expected to demonstrate central nervous system effects, particularly prolonged sedation.

Since our primary concern was to document suspected bromism in this patient, samples were assayed using a readily available gold chloride technique (Roche Biomedical Laboratories, Sacramento, CA) sensitive to 0.5 $\mathrm{mEq} \cdot \mathrm{L}^{-1}$. While this is not the preferred technique for studying bromide metabolism from halothane, the "nonbaseline" values reported in our patient (1.4-2.2 mEq. $\mathrm{L}^{-1}$ ) are within the limits of the assay and compare with the data of Tinker et al. ${ }^{2}$ The baseline level of $0.5 \mathrm{mEq} \cdot \mathrm{L}^{-1}$ represents the lowest limit of the assay.

Neither the paediatric anaesthetist nor the paediatric neuro-oncologist can easily isolate the confusing signs and symptoms of bromism from complications of cranial irradiation or tumour when dealing with the two-year-old oncology population following prolonged halothane exposure. While the impact of the bromide elevation in this patient was of little consequence, the potential for greater toxicity exists if such patients receive halothane for their initial craniotomy, particularly if the case is prolonged to debulk as much tumour as possible, and the child is further exposed to halothane during ventricular shunt placement (and revisions), and then cranial irradiation treatment protocols. While halothane is acceptable for mask induction in such a population, the use of other agents (e.g., isoflurane) may be preferable for maintenance of anaesthesia in the day surgery outpatient context. Consideration of bromide intoxication may be appropriate when using halothane in paediatric neuro-anaesthesia.

\section{References}

1 Johnstone RE, Kennell EM, Behar MG, Brummund W $J r$, Ebersole RC, Shaw LM. Increased serum bromide concentration after halothane anaesthesia in man. Ancsthesiology 1975; 42: 598-601.

2 Tinker JH, Gandolfi AJ, Van Dyke RA. Elevation of plasma bromide levels in patients following halothane anaesthesia: time correlation with total halothane dosage. Anesthesiology 1976; 44: 194-6.

3 Ewing JA, Grant WJ. The bromide hazard. South Med J 1965; 58: 148-52.

4 Barbour RF, Pilkington F, Sargant W. Bromide intoxication. Br Med J 1936; 2: 957-60.
5 Meyers EF, Charles $P$. Prolonged adverse rcactions to ketamine in children. Anesthesiology 1978; 49: 39-40.

6 Michenfelder JD. Non-barbiturate induction agents: benzodiazepines, ketamine, and etomidate. In: Michenfelder JD. Anaesthesia and the Brain, New York: Churchill Livingstone Inc., 1988; 125-7.

7 Salem MR, Bennett EJ, Schweiss JF, Baraka A, Dalal FY, Collins VJ. Cardiac arrest related to anaesthesia contributing factors in infants and children. JAMA 1975; 233: 238-41.

8 Lo JN, Buckley JJ, Kim TH, Lopez R. Anacsthesia for high-dose total body irradiation in children. Anesthesiology 1984; 61: 101-3.

9 Cronin MM, Bousfield JD, Hewett EB, McLellan I, Boulton $T B$. Ketamine anaesthesia for radiotherapy in small children. Anaesthesia 1972; 27: 135-42.

10 Fisher DM, Robinson S, Brett CM, Perin G, Gregory GA Comparison of enflurane, halothane, and isofluranc for diagnostic and therapeutic procedures in children with malignancies. Anesthesiology 1985; 63: 647-50.

11 Gronert GA, Schaner PJ, Gunther RC. Multiple halothanc anesthesia in the burn patient. JAMA 1968; 205: 878-80.

12 Friesen $R H$, Lichtor $J L$. Cardiovascular effects of inhalation induction with isoflurane in infants. Anesth Analg 1983; 62: 411-14.

13 Greene NM. Editorial views: a new aspect of the metabolism of halothane. Anesthesiology 1976; 44: 191-3. 